\title{
NOTES
}

\section{THE ANTITRUST LIABILITY OF PROFESSIONAL ASSOCIATIONS AFTER GOLDFARB: REFORMULATING THE LEARNED PROFESSIONS EXEMPTION IN THE LOWER COURTS}

\section{INTRODUCTION}

In the 1975 case of Goldfarb v. Virginia State Bar, ${ }^{1}$ the Supreme Court renounced an unlimited exemption from the Sherman Act for learned professions, ruling that such an exemption would contravene the policy underlying the Act. However, it did not declare that the learned professions were on an equal footing with business; in fact, in a much-discussed footnote, the Court specifically preserved the profession-business distinction in antitrust analysis. ${ }^{2}$ The opinion did not articulate the nature or extent of this distinction, except to say that the "public service aspect and other features" of professions should be considered. As a result, lower courts, faced with the difficult problem of formulating a more precise definition of the learned profession exemption (LPE), have been forced to carefully analyze the language of Goldfarb. In this effort, they have also relied upon the recent Supreme Court treatment of the related state action exemption (SAE). The resulting interpretations of the LPE, although scarcely uniform, have tended to emphasize the public service and state interest aspects of the professions. Further, the LPE has been treated not as an unqualified exemption but rather as a rule for the separate treatment of professional activities under the antitrust laws.

The purpose of this Note is to discuss the characteristics of the LPE as it has been developed in post-Goldfarb lower court cases. First, however, it will be necessary to examine the key elements of the Goldfarb decision as well as the relevant aspects of the recent SAE case, Cantor v. Detroit Edison $\mathrm{Co}^{3}$ The Note will then discuss lower court developments in light of this Supreme Court framework, deriving a model which incorporates the directives of Goldfarb and the "spirit" of Cantor.

1. 421 U.S. 773 (1975).

2. Id. at $788 \mathrm{n} .17$.

3. 428 U.S. 579 (1976). 


\section{THE GOLDFARB DECISION}

The development of a new analysis of the LPE, left chiefly to the lower courts, has been based upon a set of precepts and techniques extracted from Goldfarb. In that case, prospective homeowners sued the county and state bar associations in Virginia alleging that the minimum fee schedules for title examination published by the county bar association and enforced by the state bar association constituted price-fixing in violation of section 1 of the Sherman Act. Refusing to immunize either defendant under the SAE or the LPE, the Court held that the challenged activities violated the Sherman Act. There are five key elements to be examined in analyzing the Goldfarb opinion: the special malignancy of fee control activities; the factors considered by the Court in affixing the label "price-fixing" to the complamed-of activities; the vague preservation of the profession-business distinction in footnote seventeen; the analysis of the congressional intent behind the Sherman Act in relation to state action; and recognition of the compelling nature of the states' interests in the practice of the learned professions, especially law, within their boundaries.

\section{A. Fee Control Activities: A Special Case?}

The Goldfarb Court recognized the basis traditionally relied upon to distinguish professions from trades-that the goal of professional activities is not to enhance profit, but to provide services necessary for the community ${ }^{4}$-but noted that this justification "loses some of its force when used to support the fee control activities involved here."5 It went on to remark that "the examination of a land title is a service; the exchange of such a service for money is 'commerce' in the most common usage of that word. It is no disparagement of the practice of law as a profession to acknowledge that it has this business aspect . . . ."6

This language carries a strong implication that the traditional "public service versus profit"' justification for a profession-trade distinction is still

4. Thus, goes the argument, there is a possibility of harm to the public from professional competition. Semler v. Oregon State Bd, of Dental Examiners, 294 U.S. 608 (1935). The LPE had its origin in dicta in several cases arising in the early 1930's. Atlantic Cleaners \& Dryers, Inc. v. United States, 286 U.S. 427 (1932) (explicitly recognizing a learned profession-trade distinction); FTC v. Raladam Co., 283 U.S. 643 (1931) (practice of medicine is not a trade). While the distinction came to be well-recognized, see, e.g., United States v. Oregon Medical Soc'y, 343 U.S. 326, 336 (1956) (professions may deserve special consideration because of distinguishing "ethical, historical and practical" considerations), professions were nonetheless subject to antitrust laws, United States v. National Ass'n of Real Estate Bds., 339 U.S. 485 (1950) (standard real estate commissions, set by District of Columbia Real Estate Board, were held to be illegal as price-fixing); American Medical Ass'n v. United States, 317 U.S. 519 (1943) (medical profession). The Supreme Court did not rule directly on the validity of the LPE until Goldfarb. See generally Note, The End of Fee Schedules: The Sherman Act Applies to Lawyers Also, 30 U. Miami L. Rev. 464 (1976).

5. 421 U.S. at 787.

6. Id. at 787-88. 
recognized in most situations, ${ }^{7}$ but that activities primarily directed toward prices (such as fee control activities) are simply outside the protection of this public service cloak. ${ }^{8}$ Thus, under this interpretation, all professional activities would be eligible for special treatment under the LPE except those that possess two characteristics. First, the activity being restrained (for example, title examination in Goldfarb) must be "commercial" "; which, according to the Court, simply means that the activity is done in exchange for money. Under the Court's analysis, almost all professional activities will fulfill this requirement. Second, and more importantly, the restraining activity (such as publication of minimum fee schedules in Goldfarb) must relate directly to price control or stabilization. This means that the LPE may continue to cover all professional activities except those that relate to fees.

\section{B. Labeling Activities as Price-Fixing.}

The complaint in Goldfarb charged that the defendant bar associations had engaged in price-fixing by publishing minimum fee schedules which had the purpose and effect of setting price floors for title examinations. The Court was thus faced with the initial task of characterizing these activities, either as price-fixing or as permissible business practices. The importance of this characterization process cannot be overemphasized: in the absence of an exemption, price-fixing is clearly a "per se" violation of the Sherman Act. ${ }^{10}$ The Goldfarb Court, however, did not follow the same characterization procedure as is usually utilized in price-fixing cases not involving the professions.

Admitting that an advisory fee schedule would present a different question," the Court noted that "here a naked agreement was clearly shown, and the effect on prices is plain."12 Thus far, the analysis mirrored the usual search for a forbidden purpose and effect, which together are generally sufficient to constitute price-fixing. ${ }^{13}$ However, the Court went on

7. However, the distinction survives only as the basis for a rule for different treatment, rather than as an absolute exemption. See notes 20-24 infra and accompanying text.

8. For a discussion of the special importance of fee control activities, see Special Project, Recent Developments in Attorneys' Fees, 29 V AND. L. REV. 685 (1976).

9. The characterization of an activity as "business" or "commerce" is a jurisdictional prerequisite for the application of the Sherman Act, which prohibits restraints on "trade or commerce." 15 U.S.C. $\$ \S 1,2$ (1970); 421 U.S. at 788 (section 1 of the Sherman Act extends to any person engaged in business whose activities might restrain or monopolize interstate commerce). Thus, such a characterization is an essential first step in any Sherman Act analysis.

10. See, e.g., United States v. Socony-Vacuum Oil Co., 310 U.S. 150 (1940).

11. An advisory fee schedule might present a different question for two reasons. First, it would probably have a less severe anticompetitive effect. Second, the legitimate purpose of disseminating information would prevail over any anticompetitive purpose, possibly triggering first amendment protections. For a related discussion, see Branca \& Steinberg, Attorney Fee Schedules and Legal Advertising: The Implications of Goldfarb, 24 U.C.L.A. L. REv. 475, 492 (1977) and Note, supra note 4, at 467.

12. 421 U.S. at 782.

13. For example, in United States v. General Motors Corp., 384 U.S. 127, 147 (1966), the 
to point out that, due to the monopoly held by the legal profession in the area of title examination, ${ }^{14}$ the "price-fixing activities" were unusually damaging to the consumer. ${ }^{15}$ Noting "a pricing system that consumers could not realistically escape," the Court concluded that "respondents' activities constitute a classic illustration of price-fixing." 16

Since the Court did not conclusively state that the activities constituted price-fixing until after it had discussed the egregious nature of the harm involved, ${ }^{17}$ this section of Goldfarb suggests that a greater preliminary showing by the plaintiff would be required in challenging the alleged pricefixing activities of a professional association ${ }^{18}$ than in challenging nonprofessional business activities. Such an analysis would help vitiate the harshness of the implied holding that all price-fixing activities are beyond the protection of the LPE by incorporating a version of the rule of reason into the prehminary labeling process. ${ }^{19}$

\section{Footnote Seventeen: Preservation of the Distinction.}

Immediately after noting that the profession of law has a business aspect which is subject to the Sherman Act, in footnote seventeen the Court explicitly preserved the profession-trade distinction:

The fact that a restraint operates upon a profession as distinguished from a business is, of course, relevant in determining whether

Court held that the goal of restraining prices is unlawful per se when effected by combination or conspiracy even though the effect upon prices is indirect. In Northern Pac. Ry. v. United States, 356 U.S. 1, 5 (1958), the Court held that the practice of fixing prices is conclusively presumed to be harmful and illegal, without regard to the precise harm caused or the business excuse offered for its use. In United States v. Socony-Vacuum Oil Co., 310 U.S. 150, 219-20 (1940), the Court held that proof of a purpose to raise prices and proof that the challenged activities actually contributed to a price rise or to market stability, is sufficient to establish price-fixing as a per se violation of the Sherman Act. In none of these cases did the Court fcel compelled to consider the extent of the harm.

14. This monopoly was itself challenged in Surety Title Ins. Agency v. Virginia State Bar, 431 F. Supp. 298 (E.D. Va. 1977), which is discussed in the text accompanying notes 98-106 infra.

15. 421 U.S. at 782.

16. Id. at 783 .

17. The fact that the Court looked to the extent of the harm in deciding whether to label these fee schedules as "price-fixing" was mentioned in Note, Goldfarb v. Virginia State BarApplying the Antitrust Laws to the Legal Profession, 19 How. L.J. 149, 154 (1976). The same kind of "prelabeling" analysis has been proposed as a way to explain the confusion in the area of group boycotts. See Comment, Boycott: A Specific Definition Limits the Applicability of a Per Se Rule, 71 Nw. U.L. REv. 818 (1977).

18. It could be argued, however, that the Court's use of the phrase "price-fixing activities" in its discussion of the harm to the consumer indicates that the price-fixing label was affixed merely upon a showing of a prohibited purpose and effect, in accordance with the general procedure.

19. See the related discussion of United States v. National Soc'y of Professional Eng'rs, 555 F.2d 978 (D.C. Cir.), cert. granted, 98 S.Ct. 51 (1977) (No. 76-1767), in text accompanying notes $77-84$ infra. 
that particular restraint violates the Sherman Act. It would be unrealistic to view the practice of professions as interchangeable with other business activities, and automatically to apply to the professions antitrust concepts which originated in other areas. The public service aspect, and other features of the professions, may require that a particular practice, which could properly be viewed as a violation of the Sherman Act in another context, be treated differently. ${ }^{20}$

The extent to which this footnote limits the Court's prior statements is unclear. One plausible interpretation is that the antitrust concept of a per se violation, developed in the trade context, might not be carried over to cases involving the professions, to which a rule of reason test would be applied. ${ }^{21}$ This finds some meager support in the Court's consideration of the egregious nature of the harm to the consumer, ${ }^{22}$ but is weakened by the over-all flavor of the opinion, ${ }^{23}$ which seems to treat price-fixing as a per se violation even in the professional context. ${ }^{24}$ In any event, footnote seventeen clearly preserves the LPE, at least as a rule for special treatment of professional anticompetitive activities.

\section{Congressional Intent and State Action.}

After the Goldfarb Court noted that section 1 of the Sherman Act was intended to strike as broadly as possible, ${ }^{25}$ it discussed the holding in Parker

20. 421 U.S. at $788 \mathrm{n} .17$.

21. Note, however, that the LPE could really only have meaning in a per se context, since in a rule of reason case the relevant considerations (for example, state interest) can be accounted for in the normal balancing process.

22. See notes 11-19 supra and accompanying text.

23. The commentators disagree as to whether the Goldfarb Court applied a per se analysis to the price-fixing activities before it. Compare Martyn, Lawyer Advertising: The Unique Relationship Between First Amendment and Antitrust Protections, 23 WAYNE L. REv. 167, 183 (1977) (the Court declined to find a per se violation, but the burden of justifying the pernicious effect of a minimum fee schedule is so overwhelming that the only real distinction between Goldfarb and per se price-fixing cases is that the Court will consider "noncommercial" dèfenses) and Price-Fixing, Advertising Bans, and Other Self-Regulation by Lawyers: What Future Under the Antitrust Laws?, 12 CoLUM. J.L. Soc. PROB. 531, 538-40 (1976) (comments of Mr. Malina) (Goldfarb did not apply a per se rule; the lack of discussion of the reasonableness of a minimum fee schedule was the result of the Court rejecting it out of hand under the rule of reason test) with Branca \& Steinberg, supra note 11, at 507 (Goldfarb treated minimum fee schedules as a per se violation); Comment, Antitrust Law: Minimum Fee Schedules Violate the Sherman Act, 15 WASHBURN L.J. 485, 487 n.29 (1976) (the Court did not even entertain the argument that the strict per se rule should be inapplicable in Goldfarb) and Comment, Sherman Act Scrutiny of Bar Restraints on Advertising and Solicitation by Attorneys, 62 VA. L. Rev. 1135, 1143-44 (1976) (the Goldfarb Court applied a per se rule). Since the Court never discussed, or even mentioned, the issue of the reasonableness of the fee schedules, it seems most likely that a per se rule was applied.

24. Of course, the Court seems to treat price-fixing as an especially damaging practice, even compared to other per se violations. For the lower court treatment of other per se violations, see text accompanying notes 53-76 infra.

25. 421 U.S. at 787. 
v. Brown ${ }^{26}$ that the Act was intended to regulate private practices and not to prohibit a state from imposing restraints. ${ }^{27}$ Specifically, the Court said, "The threshold inquiry in determining if an anticompetitive activity is state action of the type the Sherman Act was not meant to proscribe is whether the activity is required by the State acting as sovereign."28 "It is not enough that anticompetitive conduct is "prompted' by state action . . . ."29 Thus, the Court clearly limited the extent of the SAE, leaving open the question of what additional inquiries must be made. This "limiting" attitude toward the SAE, further emphasized in Cantor v. Detroit Edison Co,${ }^{30}$ is significant in that it has influenced the development of the LPE by analogy. ${ }^{31}$

\section{E. The Compelling State Interest in the Practice of Professions.}

In the most significant part of the opinion, at least as an augur of things to come, the Goldfarb Court concluded by recognizing that states have a compelling interest in, and broad regulatory power over, the practice of professions within their boundaries. Thus, "in some instances the State may decide that "forms of competition usual in the business world may be demoralizing to the ethical standards of a profession. ",32 This state interest is especially strong im the regulation of lawyers, who as "officers of the court" are essential to the primary governmental function of administering justice. ${ }^{33}$ The Court specifically noted that its holding was not intended as a diminution of the authority of a state to regulate its professions. ${ }^{34}$

This section of Goldfarb has at least two major implications: first, it appears to vitiate the limiting language earlier in the opinion, giving the LPE a new source of life; and second, it indicates that the development of the LPE will be affected in some way by its relationship to the SAE. ${ }^{35}$ Thus, a consideration of new developments in the treatment of the SAE is relevant.

\section{CANTOR V. DETROIT EDISON Co.}

The ambiguity of Goldfarb has forced the lower courts to seek further

26. 317 U.S. 341 (1943).

27. 421 U.S. at 788.

28. Id. at 790 .

29. Id. at 791 .

30. 428 U.S. 579 (1976). See text accompanying notes $36-51$ infra.

31. See text accompanying notes 57-58 infra.

32. 421 U.S. at 792 (quoting United States v. Oregon State Med. Soc., 343 U.S. 326, 336 (1952)).

33. See notes 86-106 infra and accompanying text for a discussion of the special case of the legal profession.

34. 421 U.S. at 793.

35. This section of the opinion has been interpreted as a suggestion by the Court that the dangers of competition should hereafter be minimized by direct state regulation rather than, for example, state authorized self-regulation. Comment, Antitrust: Minimum Fee Schedules Violate the Sherman Act, supra note 23, at 489. 
guidance from Cantor $v$. Detroit Edison Co. ${ }^{36}$ a recent Supreme Court SAE case. In Cantor, the challenged activity was a light bulb exchange program initiated by the defendant utility company in 1886 and approved in 1916 by the newly-created Michigan Public Service Commission, which possessed complete power to regulate utilities. The Court assumed without opining that the activity would be an illegal restraint of competition without the approval of the Commission, and dealt solely with the effect of the Commission's approval of the program.

In deciding that the program was not exempt by virtue of a state action shield, the Court contributed three valuable analytical elements to the ongoing discussion of the relationship between the Sherman Act and state action: first, a narrow reading of Parker $\nu$. Brown $^{37}$ as holding only that action by a state official is exempt, thus emphasizing the actor rather than the activity for exemption purposes; second, an emphasis upon the relative extent of state and private participation in the decision-making process concerning challenged activities; and finally, recognition of a congressional intent to exempt private activity only to the minimum extent necessary to make a state regulatory act work.

In Parker, ${ }^{38}$ the Court held that public officials charged by state statute with the duty of administering an anticompetitive program did not violate the Sherman Act in discharging that duty. The Court stated, "The Sherman Act . . . gives no hint that it was intended to restrain state action or official action directed by a state." 39 The Cantor plurality gave Parker a very narrow reading, limiting the holding to an exemption for official action taken by state officials. ${ }^{40}$ This view of Parker is in accord with the statement in Goldfarb that the Sherman Act was intended to regulate private actions

36. 428 U.S. 579 (1976). For an exhaustive study of the evolution of the state action exemption, see Comment, The State Action Exemption in Antitrust: From Parker v. Brown to Cantor v. Detroit Edison Co., 1977 DuKE L.J. 871.

37. 317 U.S. 341 (1943).

38. Brown, a producer and packer of raisins, sought an injunction against the enforcement of a California program designed to restrict competition among growers and maintain prices in the distribution of raisins to packers. The defendants included the California Director of Agriculture and other public officials. Although Brown based his claim on his constitutional right to engage in interstate commerce, the Court, on its own motion, directed the parties to discuss the question of whether the California statute violated the Sherman Act. Finding for the defendants, the Court stated, "We find nothing in the language of the Sherman Act or in its history which suggests that its purpose was to restrain a state or its officers as agents from activities directed by its legislature." Id. at 350-51. The Court did note, however, that "[w]e have no question of the state . . . becoming a participant in a private agreement or combination by others for restraint of trade." Id. at 351-52.

39. Id. at 351.

40. 428 U.S. at $589-91$. 
and not those of the government. ${ }^{41}$ It appears that, within this narrow sphere, the exemption is absolute, regardless of the nature of the state policy behind the official action, or the nature of the action itself. ${ }^{42}$

Although the Cantor Court limited the Parker holding to action by state officials, it recognized that, in certain circumstances, private action could be protected by the SAE. Specifically, the Court stated that it would be unjust to impose Sherman Act liability upon a private actor who was merely obeying a state command. ${ }^{43}$ However, the Court conditioned the application of this "state command" aspect of the SAE upon whether the private actor had participated in the decision-making process concerning the activity. Although there could be situations where the state's participation in the decision was so dominant as to exempt the private actor, mere state authorization, approval, encouragemnent or joint participation would not be enough to trigger the exemption. ${ }^{44}$ Thus, in Cantor, the initiation of the bulb exchange program by the private defendant was enough to defeat its claim of exemption under the "state command" theory, even though subsequent state approval compelled continuation of the program until a new program was filed by the defendant and approved by the Commission.

Again, this branch of the SAE does not focus on the nature of the activity or its relation to state policy, but inerely inquires as to the involvement of the private actor in the decision to engage in the activity. ${ }^{45}$ The theory is similar to that justifying the state official action branch of the exemption; namely, that Congress did not intend to affect direct state activity by the Sherman Act, but only private actions. When a private actor has no legal alternative under state law but to engage in restrictive activity, and had nothing to do with the decision to require that activity, then the action is not really private. As there is no private volitional act which could

41. 421 U.S. at 778.

42. Note the difference between this exemption, relating to the identity of the actor, and the Cantor state regulation exemption, see text accompanying notes 47-50 infra, which focuses on the relationship between private actions and state regulatory programs. This is emphasized by the Cantor Court's statement that "the only way the legality of any program may be tested under the Sherman Act is by determining whether the persons who administer it have acted lawfully. The federal statute proscribes the conduct of persons, not programs . . ." 428 U.S. at 601 .

43. 428 U.S. at 592.

44. Id.

45. It has been argued forcefully that Cantor is susceptible of two readings concerning the prerequisites for application of the SAE to private actions required by the state. One reading is that there are two separate and distinct tests, with satisfaction of either sufficient to qualify for the exemption. These two tests are: (a) whether the decision to require the activity was that of the state, and (b) whether the activity is necessary to support a state regulatory program. The other reading is that there is only one test, requiring satisfaction of both (a) and (b) above. Dorman, State Action Immunity: A Problem Under Cantor v. Detroit Edison Co., 27 CASE W. RES. L. REv. 503, 513 (1977). Dorman prefers the second interpretation. 
be deterred, there is no sense in applying the Sherman Act; to do so would be grossly unfair to the private actor. ${ }^{46}$

The Cantor Court recognized a third branch of the SAE for activities required by state law and necessary to make a state regulatory program work. ${ }^{47}$ The theory behind this "state regulation exemption" is that Congress did not intend to impose an additional regulatory mechanism upon an area of the economy already regulated by the state. Thus, when the competitive standard imposed by the antitrust laws is actually inconsistent with the public interest standard enforced by the state regulatory agencies, and would interfere with the state regulatory program, a very limited exemption will be granted. ${ }^{48}$ Here, in determining when there is an actual conflict, the nature of the activity and the state policy involved will play important roles. ${ }^{49}$ For example, in Cantor the state regulatory interest extended to the distribution of electricity, but not of light bulbs. The Court found that there was no real interference with state policy by the particular application of the antitrust laws sought by the plaintiff and refused to grant an exemption under the "state regulation" theory. ${ }^{50}$ It is this third branch of the SAE, emphasizing that the challenged activity must be directly and necessarily connected to the success of a state regulatory program, which has been, by analogy, the central theme in the reformulation of the LPE. ${ }^{51}$

\section{LOWER COURT DEVELOPMENTS: BODDICKER AND SOCETYY OF ENGINEERS}

As noted above, the Goldfarb Court explicitly preserved the tradeprofession distinction, not as an "exemption," but as a rule for special treatment of professional activities under the antitrust laws. The Court did not explicate the characteristics that would trigger the application of this special rule, or the nature of the special treatment involved. However, it did

46. Conditioning the availability of the SAE upon the amount of participation of the individual in the decision-making process can create a difficult problem in deciding where to "draw the line." As Justice Blackmun noted in his concurrence in Cantor, 428 U.S. at 610, every state enactment is initiated by its beneficiaries. The application of a "role in the decisionmaking process" criterion might end up advantaging those who are powerful enough to lobby privately and surreptitiously. See Recent Developments, Cantor v. Detroit Edison Co., 5 Hofstra L. Rev. 673, 683 (1977).

47. 428 U.S. at 597.

48. The implication is that the SAE avoids conflicts, not between state and federal laws (which would be easy to resolve under the supremacy clause), but between state and federal systems of regulation, which the framers of the Sherman Act are deemed to have intended to coexist. See generally Boomer, Chamberlain, Horn, Weart \& Winston, Advertising Restrictions on Licensed Occupations: An Antitrust Approach, 8 ST. MARY's L.J. 729, 747 (1977).

49. The non-participation requirement of the "state command" exemption will probably have no place here, as the justifications for the two exemptions are different, although related. But see note 45 supra.

50. 428 U.S. at 598.

51. However, an "old" LPE never existed except in dicta. See note 4 supra. 
hint that fee control activities would not be exempt under any circumstances, and suggested several possible interpretations of the nature of this special treatment. The possibilities include an across-the-board application of the "rule of reason," 52 a more rigorous requirement for labeling activities as per se violations and a lower standard of judicial scrutiny of justifications for challenged professional activities, increasing their chances of surviving a balancing test.

\section{A. Boddicker v. Arizona State Dental Association.}

One significant lower court contribution to the development of the LPE is the decision of the Ninth Circuit Court of Appeals in Boddicker v. Arizona State Dental Association. ${ }^{53}$ In that case, plaintiff dentists alleged that two local Arizona dental associations and the American Dental Association $(\mathrm{ADA})^{54}$ conspired among themselves to require membership in the $\mathrm{ADA}$ as a condition precedent to membership in the local associations, thus "creating an anticompetitive tying arrangement" in violation of sections 1 and 2 of the Sherman Act. ${ }^{55}$

The district court dismissed the complaint for lack of subject matter jurisdiction under the Sherman Act and for failure to state a claim upon which relief could be granted. In reversing, the court of appeals noted that the challenged activities were no more tenuous and remote from interstate commerce than were the title examinations by lawyers that were successfully challenged in Goldfarb. It then dealt at length with the question of whether dentistry is exempt from the Sherman Act as a learned profession. ${ }^{56}$

Recognizing that the Goldfarb decision had done little to define the extent of the LPE, the Boddicker court drew upon the Cantor analysis that the SAE extended no further than was necessary to make the state regulatory program work..$^{57}$ The court used the same principle-of limiting the exemption to activities closely tied to the theoretical justifications for the exemption-in holding that "to survive a Sherman Act challenge a particular practice, rule or regulation of a profession . . . must serve the purpose for which the profession exists, viz. to serve the public. Those which only

52. See Martyn, supra note 23, at 182.

53. 549 F.2d 626 (9th Cir.), cert. denied, 98 S.Ct. 73 (1977).

54. All of the defendant associations were private, nonprofit organizations having the avowed goal of improving public health and the profession of dentistry. While membership in the local associations was not a prerequisite to the practice of dentistry in Arizona, it did carry with it substantial benefits. 549 F.2d at 626.

55. Id. at 628 .

56. The state in no way required these activities, but merely delegated regulatory authority to a state-created board of dentists. ARIz. REv. STAT. $\$ \S 32-1203,-1207$ (West 1956). Thus, the Cantor exemptions were inapplicable and, in fact, no question of state action was raised in the opinion. This illustrates that the LPE is indeed separate and distinct from the SAE, having application to situations involving private action merely approved by the state.

57. 549 F.2d at 631 . 
suppress competition between practitioners will fail to survive the challenge." 58

After announcing this test, the court summarily noted that the challenged activities were not so obviously designed to improve dental services to the public as to permit it to sustain a motion to dismiss the complaint. The case was then remanded to the lower court. Further proceedings would allow the plaintiff to demonstrate the extent of the tying arrangements' anticompetitive effects, and the defendants to demonstrate the benefits of the practice. ${ }^{59}$

\section{The criteria which trigger the application of the learned profession exemption.}

Although dealing mainly with the nature of the LPE, Boddicker of necessity also contained implications as to the conditions of its application. For example, the court assumed without discussion that dentistry was a learned profession eligible for special treatment. The only special characteristic of the defendant associations mentioned by the court was that all were non-profit organizations. ${ }^{60}$

The court also ignored the fact that the alleged tying arrangements, if proved, would constitute a per se violation of the Sherman Act. ${ }^{61}$ The clear implication. is that the LPE is to be applied regardless of whether the challenged activities would be classed as a per se violation in other contexts. This seems inconsistent with Goldfarb, which applied standard antitrust analysis to professional fee control activities. However, Goldfarb can be

58. Id. at 632.

59. Id.

60. The lower courts have not dealt specifically with the definition of a "learned profession," although inferences can be drawn from their holdings and from the theory behind the LPE. Specifically, in each case where the courts have treated a livelihood as a profession in the antitrust context, the state has delegated it self-regulatory powers. E.g., D.C. CODE ENCYCL. §§ 2-1803, -1805, -1808 (West 1966). This is the best criterion for defining a "learned profession," because the LPE is based on the theory that the state has imposed a non-competitive standard upon professions by allowing them to regulate themselves, in effect allowing them limited monopoly powers.

To complicate the classification further, the majority in Virginia State Bd. of Pharmacy v. Virginia Citizens Consumer Council recognized the possibility of distinction between professions, saying:

The distinctions, historical and functional, between professions, may require consideration of quite different factors. Physicians and lawyers, for example, do not dispense standardized products; they render professional services of almost infinite variety and nature, with the consequent enhanced possibility for confusion and deception if they were to undertake certain kinds of advertising.

425 U.S. 748, 773 n.25 (1976) (emphasis in original). This possibility has not been explored in the cases, but the District of Columbia Circuit Court of Appeals, in United States v. National Soc'y of Professional Eng'rs, 555 F.2d 978 (D.C. Cir.), cert. granted, 98 S. Ct. 51 (1977) (No. 761767), did leave open the possibility of distinguishing between professions for purposes of LPE analysis. 555 F.2d at 982; see text accompanying notes 77-84 infra.

61. E.g. , Fortner Enterprises, Inc. v. United States Steel Corp., 394 U.S. 495, 498 (1969) (a tying arrangement is a per se violation of the Sherman Act). 
construed narrowly as applying only to fee control activities, and not to other per se violations like tying arrangements. ${ }^{62}$ Such a reading is suggested by the Boddicker court's failure to consider the per se nature of tying arrangements as an obstacle to the application of the LPE. Thus, when read in conjunction with Goldfarb, Boddicker suggests that all traditional per se violations except price-fixing will be eligible for the LPE.

\section{The nature of the LPE.}

The main contribution of the Boddicker opinion is its discussion of the nature of the special treatment to be accorded eligible activities under the LPE. To survive a Sherman Act challenge, the activity must serve the purpose for which the profession exists: it must contribute directly to improving service to the public. An activity which only supresses competition among practioners will not survive the challenge. ${ }^{63}$ As noted above, this "public benefit" defense will apply even to those professional activities which fall within most traditional per se categories of offenses. Unfortunately, Boddicker does not make clear the way in which the public benefit analysis is to be conducted nor the extent to which the challenged practice must serve the public interest in order to overcome its anticompetitive effect.

The court's language can be read to indicate that the "direct contribution to public benefit" requirement for exemption is invariant in degree, regardless of the extent of the anticompetitive effects of the challenged activities. Of course, in areas traditionally subject to rule of reason analysis, even if the activity is not so closely tied to the public benefit as to win the profession exemption, it may survive the Sherman Act challenge due to a minimal anticompetitive purpose and effect. However, the language of Boddicker implies that, im per se areas such as tying arrangements, the anticompetitive effect will be presumed, and a fixed standard of benefit must be reached to win exemption. To this extent the per se analysis would be retained, but only as evidence of a fixed degree of harm to be balanced against the benefits. A remaining question is whether classification of an activity as a traditional per se violation would be conclusive or only presumptive evidence of harm.

The general approach suggested in Boddicker was taken by a federal district court in Feminist Women's Health Center, Inc. v. Mohammad, ${ }^{64}$ a

62. Footnote seventeen is good authority for such a construction. See text accompanying notes 20-24 supra. See also the dissent of Judge Fitzgerald in Boddicker, 549 F.2d at 633-34, discussed in note 76 infra.

63. $549 \mathrm{~F} .2 \mathrm{~d}$ at 632 .

64. 415 F. Supp. 1258 (1976), modified on other grounds, No. TCA 75-186 (Dec. 3, 1976), appeal docketed, No. 77-1924 (5th Cir. 1977). Here a women's health center which provided first trimester elective abortions sued several physicians, alleging that they had engaged in a group boycott in violation of the Sherman Act. Finding that the plaintiff had sustained its 
1976 Florida case involving an alleged economic boycott by a medical association. The historical effect of pleading a per se violation such as a boycott ${ }^{65}$ was to free the plaintiff from having to show that the restraint was unreasonable, or that it harmed the public, these elements being presumed conclusively. In addition, evidence of good intentions, or of public benefit, was deemed irrelevant. ${ }^{66}$ However, Goldfarb made the professions a special case under the antitrust regulatory scheme, requiring that the impact of state regulation and policy be measured in any action against professionals. Thus, the question faced by the Feminist court was whether the per se doctrine could be applied at all in such a case and, if so, to what extent. ${ }^{67}$

The court felt that the per se doctrine should be applied to some extent since "whatever else it may be, the medical profession constitutes in large part the rendering of a service for money and is in that sense a business. Moreover, . . . an economic boycott . . . carried out by members of the medical profession is no less antithetical to free competition than is an economic boycott carried out by nonprofessionals." ${ }^{68}$ However, since Florida had delegated self-regulation responsibilities to the medical profession, good intentions would be a defense even to a per se violation. The court felt that this would protect the state's interest in regulating its professions, while recognizing the federal policy behind the Sherman Act. Under this approach, the plaintiff would have to prove only that the defendant engaged in a combination or conspiracy in the nature of a boycott; then the defendant would have the opportunity of proving good faith to rebut the per se presumption of unreasonableness. ${ }^{69}$

Feminist can be criticized for allowing a "good faith" defense, particularly since the plaintiff was inerely seeking a preliminary injunction. ${ }^{70}$ Whatever the applicability of the defendant's good faith in an action seeking to subject him to personal liability, ${ }^{71}$ it is not a relevant consideration in

burden of establishing a substantial probability of success on the merits, the court nonetheless denied preliminary injunctive relief on the ground that the plaintiff failed to demonstrate sufficient likelihood of irreparable harm prior to a trial on the merits. $415 \mathrm{~F}$. Supp. at 1270-71.

65. The group boycott is labeled a per se violation, Fashion Originators' Guild of America, Inc. v. FTC, 312 U.S. 457, 467-68 (1941), but is often treated as being subject to the rule of reason. See Comment, supra note 17. See also McCormick, Group Boycott-Per Se or Not Per Se, That is the Question, 7 SETON HALL L. Rev. 703 (1977). This might help explain the fact that a boycott does not receive per se treatment in the professional context of Feminist. However, the court's language seems to apply to other, more accepted per se violations as well.

66. Cf. Northern Pac. Ry. v. United States, 356 U.S. 1, 5 (1958).

67. 415 F. Supp. at 1263.

68. Id.

69. Id.

70. Id. at 1262 .

71. For example, in the context of the SAE, the Cantor plurality seemed to recognize "unfairness" as a defense to an action for treble damages. 428 U.S. at 599. 
reconciling the state and federal interests in a professional activity alleged to restrain competition. The LPE is based on the theory that activities which are presumed to be harmful in a free market context because of anticompetitive effects might in fact not be harmful in a professional context, due to the public interest regulatory scheme enforced by the state. ${ }^{72}$ An interpretation of the LPE which bases it upon good intentions misses the point, since it does not make the exemption contingent upon the actual effects of the activities in the professional context. The Boddicker public benefit defense is clearly superior, particularly in view of Cantor's emphasis upon the necessity of a close relationship between the effects of the challenged activities and their theoretical justification.

More interesting is Feminist's retention of the per se rule as conclusive evidence of harm, while allowing a defense not generally available in per se contexts. This position is in accord with the reading of Boddicker mentioned above. The Feminist court justified its approach by noting that the anticompetitive effect of the challenged activities will not vary between professional and business contexts, since professions have a business aspect. ${ }^{73}$ This is true, but the court makes the mistake of equating anticompetitive effect with the harm to be plugged into a balancing equation. The same reasoning that supports the recognition of a "benefit defense"ent context of professional activities-also supports a requirement that the plaintiff prove actual harm to the public from the anticompetitive effects of the defendant's activities. It is entirely possible that such anticompetitive activities would not be harmful due to the effectiveness of the state's regulatory program enforcing a public interest standard rather than a competitive standard. Per se rules should not be applied until judicial familiarity with such contexts has reached a more advanced state. At most, the per se classification of challenged professional activities should create a presumption of harm.

An alternative, and better, interpretation of Boddicker, indicated by the court's instructions on remand, ${ }^{74}$ is that the LPE is really an exemption from the application of per se rules, and that where it is available the court will conduct a rule of reason analysis even in the most traditional per se areas. As noted above, such a balancing approach accurately reflects the underlying justification for a learned profession distinction, ${ }^{75}$ allows flexibility and encourages the input of information in an unfamiliar context.

72. See note 4 supra.

73. 415 F. Supp. at 1263.

74. The district court was instructed to consider the extent of both the anticompetitive effect and the benefit. 549 F.2d at 632 .

75. It has been suggested that the state interest basis of the LPE should result in a very lax standard of judicial review of professional activities: 
Under this reading, Boddicker tracks the implications of footnote seventeen in Goldfarb by establishing an across-the-board balancing test for anticompetitive professional activities. Recognizing the state interests behind the LPE, the Boddicker court required that the activity be sustained only if its direct contribution to the public benefit outweighs its anticompetitive effects. The limiting language of Goldfarb and Cantor was thereby honored while the underlying policies of the LPE were heeded. In conducting the balancing test, the court indicated that it would employ an active standard of review, requiring an actual showing of public benefits and harmful anticompetitive effects, rather than relying on presumptions evolved in other areas. ${ }^{76}$

\section{B. United States v. National Society of Professional Engineers.}

Although Boddicker effectively combined the implications of Goldfarb and Cantor into a workable rule, it left some gaps in the emerging picture of the LPE. Particularly, the question of whether the special balancing test would apply to professional price-fixing activities was left unresolved. The opinion of the District of Columbia Circuit Court of Appeals in United States v. National Society of Professional Engineers ${ }^{77}$ helps to complete the picture.

In Society of Engineers, it was alleged that the efforts of the National Society of Professional Engineers (Society) to enforce a provision of its Code of Ethics prohibiting any form of competitive bidding on engineering projects violated the Sherman Act. The Society argued that Goldfarb left room for restraints on competition among professionals which serve a reasonable objective. It then attempted to justify the rule by claiming that it served to eliminate the deception and poor execution likely to result from competition. In the course of holding the Society's activities in violation of

If, for example, the justification for the [anticompetitive] scheme lies in the protection of health or safety, the strength of that justification is forcefully attested to by the existence of a state enactment. I would assess the justifications of such enactments in the same way as is done in equal protection review, and where such justifications are at all substantial (as one would expect them to be in the case of most professional licensing or fee-setting schemes, for example . . .), I would be reluctant to find the restraint unreasonable.

Cantor, 428 U.S. at 611 (Blackmun, J., concurring). This reasoning seems to ignore congressional intent to strike as broadly as possible with the Sherman Act, as well as the existing safeguards for state integrity in the antitrust area. Boddicker, exemplifying a very active standard of review, seems to be a better approach.

76. Judge Fitzgerald, in dissent, gave Goldfarb an entirely different reading, construing it narrowly as holding only that certain business or commercial aspects of professions are subject to regulation. 549 F.2d at 633. This interpretation ignores the language of footnote seventeen and the lesson of Cantor, made applicable to the LPE by Goldfarb's emphasis on the similar policies underlying the LPE and the SAE. Both strongly imply that professional activities will not win an absolute exemption under any circumstances.

77. 555 F.2d 978 (D.C. Cir.), cert. granted, 98 S.Ct. 51 (1977) (No. 76-1767). 
the Sherman Act, the court dealt at length with the treatment to be given alleged professional price-fixing activities.

Initially, the court of appeals upheld the district court's finding that the challenged activities constituted price-fixing, quoting with approval the district court's discussion:

In determining that the fee schedule in Goldfarb constituted a price-fixing practice, the Court emphasized the nature of the restraint, the enforcement mechanism, and the fee schedule's adverse impact upon consumers.

... Since engineering services are indispensable to almost any construction project, and since alternative sources . . . are non-existent, the impact upon the public of defendant's pricing restraint is plain. ${ }^{78}$

Here, as in Goldfarb, it appears possible that the court required a showing different from that ordmarily required to label activities price-fixing by focusing on an examination of actual harm to the consumer. Under this approach, the rule of reason would be applied in the labeling process rather than in the process of determining whether the activities should be characterized as violating the Sherman Act.

After characterizing the activities as "price-fixing," the court of appeals upheld the district court's application of a per se rule, emphasizing the singularly important role played by competitive pricing in the market. ${ }^{79} \mathrm{It}$ qualified its approval by saying that a price-fixing rule stands at least presumptively condemned in a way that does not apply to other trade practice rules. As the Society's rule was on its face universal in application, it was presumptively condemned. However, the district court "did not take the rule solely on its face, and reach a condemnatory result merely because of an unfortunate use of language. It assessed the rule by taking into account how it had operated in fact, and with what practical anti-competitive consequences." 80 This was enough; "[s]ound antitrust doctrine did not require a simulation of a 'cost-benefit ratio' analysis, or a 'balancing' of the benefits accrumg from competitive restraints of this nature." 81 There was no examination of benefits. This section of the opinion, although unclear, seems to retain the application of some sort of per se rule of at least presumptive condemnation. Further, the "benefit defense"' of Boddicker appears to be unavailable in price-fixing contexts. However, the Society of Engineers court wavered on this latter point.

78. 555 F.2d at 981 n. 3 (quoting United States v. National Soc'y of Professional Eng'rs, 404 F. Supp. 457,460 (D.D.C. 1975)).

79. $555 \mathrm{~F} .2 \mathrm{~d}$ at 981.

80. Id. at 982 .

81. Id. 
The court went on to state that it did not mean to imply that there was no room in antitrust law for ethical rules of practice for the learned professions. The Society's broad ban was simply not justified by the vague rationalization offered in its defense-the prevention of harm to the public. The prohibition did not "take into account the sophistication of the purchaser, the complexity of the project, or the procedures for evaluating price information." 82 The court strongly hinted that a refined rule, more limited in its objectives and restraints, might be acceptable in light of the "legitimate objective of preventing deceptively low bids." 83 In concluding, the court noted that price-fixing is generally deemed conclusively unreasonable, but that an exception might be made for ethical rules of professional associations narrowly confined to interdiction of abuses. ${ }^{84}$ Thus, in this section of the opinion, the court adopts the Boddicker approach, allowing a defense for activities closely tied to the intended benefits, while continuing to recognize at least a presumption of harm from per se activities.

Society of Engineers does not give as clear a picture of LPE analysis in the price-fixing context as might be hoped. Surprisingly, the one certainty is the price-fixing activities are not to be conclusively condemned as unreasonable. The strong implications of Goldfarb are ignored in this regard. At most, the harmful effects of the activities will be presumed, possibly conclusively, but a narrow Boddicker-like defense may be available. In theory, this is as eminently reasonable a result as that reached in Boddicker, but it is harder to justify in light of Goldfarb, which gave no indication that any sort of benefit defense would be allowed in price-fixing contexts.

\section{The Boddicker-Society of Engineers Model.}

After Boddicker and Society of Engineers, the LPE can be characterized as a rule of special treatment for anticompetitive activities of professional associations, rather than as an absolute exemption. The special treatment applies only to those activities historically classed as per se violations of the Sherman Act; for other sorts of activities, the special factors present in a professional context can and presumably will be incorporated in the rule of reason balancing test. Although the characteristics of the LPE as developed in the lower courts have not yet been approved by the Supreme Court, they are generally consistent with the implications of Goldfarb and Cantor, as well as with the Supreme Court's most recent pronouncement on the SAE. ${ }^{85}$

82. Id.

83. Id. at 983 .

84. Id.

85. For example, see the discussion of Bates v. State Bar of Ariz., 97 S. Ct. 2691 (1977), in text accompanying notes 87-94 infra. 
The outlines of the LPE can be portrayed as a lock-step series of questions. Assuming that the defendant's activities qualify as professional, the court will first inquire if they constitute "price-fixing." For such a label to be affixed in professional contexts, it is possible that the court will require that the plaintiff show a public harm resulting from the activities, as well as the traditional elements. If the plaintiff meets this burden, and the activities are labeled "price-fixing," the result is unclear. The most likely interpretation is that harm will be presumed, perhaps conclusively; but a defense will be allowed if the defendant can show that the activities are not overly broad in light of their legitimate objectives, and have a direct beneficial effect in helping to achieve these objectives. On the other hand, if the activities are not labeled price-fixing, they will undergo a balancing test, weighing the actual harm against the demonstrable public benefits.

The model seems to be a good one. It reflects recent developments in the SAE, which are appropriate due to the similar underlying rationales of the two exemptions; and in substituting a balancing test for an absolute exemption it severely limits the scope of immunity, honoring the congressional intent behind the Sherman Act.

\section{THE RELATIONSHIP BETWEEN THE CANTOR SAE AND THE BODDICKER LPE: The SPECIAL CASE of tHe Legal Profession}

Goldfarb emphasized that the legal profession would occupy a special position in antitrust analysis because of its dual status as a profession and a part of the state governmental machinery. ${ }^{86}$ On the one hand, activities of a legal professional association might win exemption under the Boddicker public benefit defense; on the other, they might be exempt by virtue of governmental connections under the Cantor SAE theory. This raises the interestimg question of the relationship between the tests applied under the two exemptions.

One difference between the two exemption theories, clearly favoring the legal profession over all others, is that the SAE grants an unqualified immunity to direct actions by state officials. That this immunity is likely to be available to the legal profession is indicated by the Supreme Court's holding in Bates $v$. State Bar of Arizona, ${ }^{87}$ where plaintiff attorneys challenged the validity of a state supreme court disciplinary rule prohibiting attorney advertising. The Court had no trouble deciding that the SAE applied to insulate the rule from Sherman Act liability, ${ }^{88}$ even though the

86. 421 U.S. at 793 (1975). See text accompanying note 33 supra.

87. 433 U.S. 350 (1977).

88. An interesting problem is raised by the position of advertising prohibitions under the fourteenth amendment and the Sherman Act: a certain minimum level of state action is required to trigger the SAE, while a certain maximum of state action is allowed before the prohibition 
only question before the Court involved price advertising. ${ }^{89}$ Cantor was distinguished on the ground that, in Bates, the claims were asserted directly against the state. "The Arizona Supreme Court is the real party in interest; it adopted the rules, and it is the ultimate trier of fact and law in the enforcement process. . . . Although the State Bar plays a part in the enforcement of the rules, its role is completely defined by the court; the appellee acts as the agent of the court under its constant supervision." 90 As the court is the ultimate body wielding the state's power over the practice of law, its actions in that context are actions of the state. ${ }^{91}$ Furthermore, whereas in Cantor the challenged restraint did not involve any important state policy or interest, "the regulation of the activities of the bar is at the core of the state's power to protect the public." 92 In Bates, "the disciplinary rules reflect a clear articulation of the State's policy with regard to professional behavior."

The lesson of Bates is that self-regulating activities of the legal profession, generally done under the supervision of the state supreme court, will be in a good position to win exemption under the direct "state-action" branch of SAE. The participation of the supreme court will tend to bring the restraints under the heading of direct state action. ${ }^{94}$ Bates may thus produce a much greater participation of state supreme courts in the establishment of rules of professional conduct, as state bar associations strive to move from the Goldfarb approach to the Bates approach.

The most interesting comparison between the two exemption theories involves private actions. If the professional defendant can show that his

violates the fourteenth amendment. In fact, it is arguable that the level of state involvement which will trigger the fourteenth amendment is below that which is required to activate the SAE, in light of Cantor's stringent requirements. See text accompanying notes 36-50 supra; see generally Martyn, supra note 23, at 197.

89. The Court did not reach the question of the applicability of the LPE to the restraint on advertising, as the SAE was held to apply. Although not likely to arise, given the Bates alternative, it is interesting to speculate on the fate of rules restraining attorney advertising which are for some reason not qualified to win the SAE. Such rules might not fall within per se categories (even apart from their professional context); and they occupy a central position in the system of lawyer self-regulation. Branca \& Steinberg, supra note 11, at 509-21. Thus, they would most likely be upheld under an LPE analysis.

90. 433 U.S. at 361.

91. Id.

92. Id.

93. Id. at 362 .

94. It is possible to categorize the sources of restrictions on professional competitive activities as either: (a) state statutes; (b) rules promulgated by state licensing boards; (c) regulations initiated by private actors and adopted by the state; and (d) rules made and enforced solely by private associations. See Boomer, Chamberlain, Horn, Weart \& Winston, supra note 48, at 732-33. Identifying the source of a particular restriction is essential to an assessment of its legality under antitrust law. For lawyers, the second category, rules promulgated by a state licensing board, will often actually be rules promulgated by the state supreme court, thus making the SAE available without regard to the nature and effect of the rule. 
activities were required by the state, ${ }^{95}$ the third branch of the SAE will be available, allowing the defendant to show that his actions were necessary to make a state regulatory program work and that they were not overly broad in accomplishing that objective. Failing such a direct connection, or the necessary finding that the activity was required by the state, the Boddicker public benefit defense would still be available. What are the differences, if any, between the two tests?

The two tests are phrased differently: the emphasis in the SAE test is upon the connection between the challenged activities and the successful continuation of an announced state regulatory policy; the LPE test emphasizes a relative weighting of the harms and benefits of the activities, without specific reference to state regulatory programs. Nonetheless, the difference is chiefly one of semantics. In conducting the LPE test, the benefits will presumably be articulated and measured in terms of state policy objectives in much the same fashion as is done in a Cantor analysis. In this view, the LPE is essentially an application of the SAE without the prerequisite that the activity be required by the state; the gap is filled by the requirement that the state must have delegated self-regulatory power to the occupation in order for it to qualify as a learned profession. ${ }^{96}$

A pre-Bates district court case having a close factual connection to Goldfarb $^{97}$ illustrates the relevance of both LPE and SAE analysis to antitrust problems in the legal profession. In Surety Title Insurance Agency, Inc. $v$. Virginia State Bar, ${ }^{98}$ the plaintiff title company claimed that the Virginia State Bar's practice of issuing advisory opinions relating to ethics and the unauthorized practice of law, coupled with the threat of disciplinary proceedings, constituted an illegal group boycott in violation of the Sherman Act. These advisory opinions, rendered in a non-adversarial context and available only to attorneys, were issued by the state bar as an administrative agency of the Virginia Supreme Court ${ }^{99}$ and pursuant to a specific grant of

95. Again, this is more likely to be true in the case of a lawyer than for any other professional. Most professions are regulated under rules established by a board comprised of private practitioners and delegated authority by state statute. Such rules are merely "authorized" by the state. However, in many cases, the rule-establishing body for the profession of law is the state supreme court, which is a branch of the state government. Any rules promulgated by the state supreme court will thus be "requirements" of the state.

96. See note 60 supra.

97. In Goldfarb, the challenged activities were the publication of minimum fee schedules for title examination. In its discussion, the Goldfarb court noted that the harm was aggravated by the monopoly held by the legal profession in the field of title examination. In Surety Title Insurance Agency, Inc., v. Virginia State Bar, 431 F. Supp. 298 (E.D. Va. 1977), that monopoly itself was challenged as a boycott. See text accompanying notes 98-106 infra.

98. 431 F. Supp. 298 (E.D. Va. 1977).

99. VA. CODE § 54-49 (1974). 
power by the court. ${ }^{100}$ The effect of the opinions was to require the participation of an attorney in title insurance transactions, making it impossible for the plaintiff to carry out its plan to reduce prices by eliminating attorney middlemen. The court found that plaintiff's plan would result in the consumer receiving greater services at a lower cost, ${ }^{101}$ and held that the issuance of such advisory opinions was a classic illustration of a group boycott. ${ }^{102}$

The court then reviewed recent cases on the SAE and the LPE in search of principles to be applied to anticompetitive activities of the legal profession. Merging the requirements of the two exemptions, the court first inquired whether the activity was compelled by the state acting as sovereign. Since the state bar was required by the state supreme court to render advisory opinions at the request of a member, the court held that the issuance of advisory opinions was a product of a state command. ${ }^{103}$ Unlike the rule in Bates, however, the content of the issued opinions was within the discretion of the state bar, and thus faced additional tests. The court drew from Boddicker and Cantor the "common thread of focusing on the relationship between the anticompetitive activity and the state interest it purports to advance. If that relationship is tenuous the activity must fall."104

Under this analytical scheme, the court held that the advisory opinions violated the Sherman Act. The intended benefit was assurance that only qualified people would render legal services, and that people rendering such services would be subject to the Virginia Code of Professional Responsibility. Both considerations advance the public interest by "insuring the quality of the legal services and imposing upon lawyers a degree of accountability to the state." 105 However, the advisory opinion process was held not sufficiently related to these interests to justify its anticompetitive effects. ${ }^{106}$ In so deciding, the court noted the availability of less restrictive alternative means such as the imposition of criminal sanctions.

The striking feature of the court's opinion is that it failed to make any distinction between the LPE and the SAE, combining the Boddicker and

100. The Supreme Court of Virginia is legislatively empowered to define what constitutes the practice of law. 431 F. Supp. at 300; VA. CODE § 54-48(a) (1974).

101. 431 F. Supp. at 303.

102. Group boycotts are said to be per se violations of the Sherman Act. Silver v. New York Stock Exch., 373 U.S. 341, 347 (1962). In Surety Title, the court noted that "there is a split of authority as to whether the per se or rule of reason test should be applied to substantive antitrust claims involving the practices of professions. . . . The court need not reach this issue as it concludes that the practice in question cannot withstand the less demanding rule of reason and analysis." 431 F. Supp. at 304 n.8.

103. 431 F. Supp. at 307.

104. Id. at 306 .

105. Id. at 307 .

106. Id at 307-08. 
Cantor tests without discussion of their different contexts. Since the case involved the legal profession, which is often eligible for both exemptions, there was no need to distinguish between the two tests in terms of the prerequisites of their application; but the additional failure of the court to discuss the relative characteristics of the two tests supports the conclusion that they are in fact quite similar, despite their different language. Thus, although the court's finding that the advisory opinions were required by the state could be challenged, the same test, phrased differently, would still be available under the LPE.

Surety Title interprets the SAE and the LPE as two sides of the same coin. The chief difference is that the "direct connection-minimum extent necessary" balancing test will be called the SAE when applied to activities required by the state, and the LPE when applied to activities of professional associations exercising self-regulatory power delegated by the state.

\section{CONCLUSION}

In Goldfarb, the Supreme Court denied that the learned professions were entitled to an absolute exemption from the antitrust laws, but left open the possibility that they might receive some sort of special treatment. The Court did not specify the nature of this special treatment, although it did emphasize the interests of the states in regulating the professions. Then, in Cantor, state regulatory interests were recognized and protected by an exemption extending to private activities required by the state and essential to the maintenance of a state regulatory program. Drawing from Cantor, the lower courts, particularly in Boddicker and Society of Engineers, have developed the outlines of the "new" learned profession exemption. Anticompetitive activities, with the possible exception of price-fixing, will be subject to a rule of reason analysis balancing their direct contribution to the public benefit against their harmful anticompetitive effects. This test, employed even in per se categories, shares with the Cantor test the requirement that the anticompetitive activity be directly connected to the state regulatory interest, and have only the minimum anticompetitive effect necessary. In fact, despite the different language of the two tests, they are quite similar in operation. The chief difference is that the balancing test is called "the state action exemption" when applied to activity required by the state, and "the learned profession exemption" when applied to the activities of an association which has been delegated self-regulatory powers by the state. The states have a special interest in regulating the profession of law, as noted in Goldfarb. This is reflected in the substantial protection that bar associations receive under both exemptions, and particularly, as im Bates, in the absolute immunity granted to direct state action. 